Article

\title{
Selective Leaching of Vanadium from Roasted Stone Coal by Dilute Sulfuric Acid Dephosphorization-Two-Stage Pressure Acid Leaching
}

\author{
Jun Huang ${ }^{1,3}$, Yimin Zhang ${ }^{1,2,3, *}$, Jing Huang 1,2,3, Tao Liu ${ }^{1,2,3}$, Zhenlei Cai ${ }^{1,2,3}$ and \\ Nannan Xue ${ }^{1,2}$ \\ 1 College of Resources and Environmental Engineering, Wuhan University of Science and Technology, \\ Wuhan 430081, China; 15972153558@163.com (J.H.); jing_huang81@126.com (J.H.); \\ liutao781019@126.com (T.L.); caizhenlei@wust.edu.cn (Z.C.); cbdis@aliyun.com (N.X.) \\ 2 Hubei Provincial Engineering Technology Research Center of High Efficient Cleaning Utilization for Shale \\ Vanadium Resource, Wuhan 430081, China \\ 3 Hubei Provincial Collaborative Innovation Center for High Efficient Utilization of Vanadium Resources, \\ Wuhan 430081, China \\ * Correspondence: zym126135@126.com; Tel.: +86-27-6886-2057
}

Academic Editor: William Skinner

Received: 8 May 2016; Accepted: 8 July 2016; Published: 21 July 2016

\begin{abstract}
A novel staged leaching process has been reported in this paper to selectively extract vanadium from roasted stone coal and the mechanisms have been clarified. Results showed that the leaching efficiency of $\mathrm{V}, \mathrm{Al}, \mathrm{P}$ and $\mathrm{Fe}$ was $80.46 \%, 12.24 \%, 0.67 \%$ and $3.12 \%$, respectively, under the optimum dilute sulfuric acid dephosphorization (DSAD)-two-stage pressure acid leaching (PAL) conditions. The efficient separation of $\mathrm{V}$ from $\mathrm{Fe}, \mathrm{Al}$ and $\mathrm{P}$ was realized. As apatite could be leached more easily than mica, the apatite could completely react with sulfuric acid, while the mica had almost no change in the DSAD process, which was the key aspect in realizing the effective separation of $\mathrm{V}$ from P. Similarly, the hydrolyzation of $\mathrm{Fe}$ and $\mathrm{Al}$ could be initiated more easily than that of $\mathrm{V}$ by decreasing the residual acid of leachate. The alunite and iron-sulphate compound generated in the first-stage PAL process resulted in the effective separation of $\mathrm{V}$ from $\mathrm{Fe}$ and $\mathrm{Al}$.
\end{abstract}

Keywords: pressure acid leaching; stone coal; thermodynamics; vanadium; selective leaching

\section{Introduction}

In China, the gross reserve of vanadium in stone coal was 118 million tons in the terms of $\mathrm{V}_{2} \mathrm{O}_{5}$ [1,2]. The vast amount of these deposits has made stone coal be of considerable interest as a vanadium source. As for the traditional vanadium extraction process from stone coal, the salt roasting-water leaching technology was already eliminated due to the low vanadium recovery and the serious environmental pollution [3]. Recently, the acid leaching process for vanadium extraction from stone coal after oxidizing roasting, which was efficient and environmental-friendly, has attracted increasing attention, and the pressure acid leaching (PAL) process, with advantages of higher recovery and shorter production cycle, has become the research hotspot in this area [4,5]. However, the impurities content in leachate is usually very high [6]. These impurities, particularly the $\mathrm{Fe}, \mathrm{Al}$ and $P$, could decrease the recovery of vanadium in a series of ways: Fe will be accumulated in the D2EHPA/TBP (Bis(ethyl)-phosphonic acid/Tributyl phosphate) [7], which results in the reduction of solvent saturation capacity; $\mathrm{Al}$ will also be accumulated in the D2EHPA/TBP, which results in a sharp decrease of vanadium extraction ratios [8]; $\mathrm{P}$ will combine with vanadate ions to produce 
heteropolyacid anions, which inhabits the precipitation of ammonium vanadates [9]. Therefore, it is urgent to solve the problem of selectively leaching vanadium from the roasted stone coal, which still remains a challenge in industrial operations.

The effective separation of valuable metals from impurities had been realized in many other fields by selective leaching technology. Xia studied the removal of phosphorus from high phosphorus iron ores by selective $\mathrm{HCl}$ leaching method and found that, under proper conditions, the removal rate of phosphorus could exceed 98\% [10]. The removal of phosphorus from high phosphorus iron ores using acid leaching had also been investigated by Chen and Jin, and the high removal rate of phosphorus has been realized [11,12]. Their studies showed that it is possible to realize the effective separation of V from P by DSAD. On the other hand, Önal investigated the PAL of Çaldağ lateritic nickel ore and found that, under high temperature reaction conditions, the Fe and Al leached were re-precipitated as hematite and alunite respectively and decreasing the residual acid of leachate could accelerate the precipitation of Fe and Al [13]. For decreasing the residual acid of leachate, the two-stage PAL process was usually used and a good effect could be obtained [14]. Moreover, the two-stage acid leaching was also cost-effective due to the lower acid consumption [1]. Thus, it was possible to achieve the effective separation of $\mathrm{V}$ from Fe and $\mathrm{Al}$ by two-stage PAL.

In this study, the effect of sulfuric acid concentration and temperature on dephosphorization efficiency and vanadium loss has been studied. Then the effect of various factors such as the first-stage initial sulfuric acid concentration, the first-stage leaching temperature, the second-stage sulfuric acid concentration and the second-stage leaching temperature on the leaching of $\mathrm{V}, \mathrm{Fe}, \mathrm{Al}$ and $\mathrm{P}$ were studied. Finally, X-ray diffraction (XRD), X-ray photoelectron spectroscopy (XPS) and thermodynamics analysis were carried out to study the basic principles on the selective leaching of vanadium from roasted stone coal.

\section{Experimental}

\subsection{Materials}

In this work the stone coal was obtained from Tongshan located in Hubei Province, China. The raw ore was crushed to $-3 \mathrm{~mm}$ and it was roasted in a SXZ-10-B muffle furnace (Shanghai Experimental Furnace Plant, Shanghai, China) at $850{ }^{\circ} \mathrm{C}$ for $60 \mathrm{~min}$ and then dry ground to $80 \%-0.074 \mathrm{~mm}$ in size with a XZM-100 vibration mill (Wuhan Hengyue Mineral Engineering Company, Wuhan, China). The roasted and gained ore was referred to as the roasted stone coal throughout this work.

The main chemical composition of roasted stone coal was analyzed by inductively coupled plasma atomic emission spectroscopy (ICP-AES) (Thermo Scientific, Waltham, MA, USA) listed in Table 1. It was indicated that the composition of roasted stone coal was complex. The roasted stone coal was mainly composed of quartz, hematite, gypsum, calcite and mica (Figure 1). The vanadium that existed in mica was mainly in the form of lattice replacement according to the study of Zhang [15]. The quantitative evaluation of minerals by scanning electron microscopy (QEMSCAN) analysis (FEI, Hillsboro, OR, USA) (Figure 2) of roasted stone coal showed that there were small amounts of apatite existed in this roasted stone coal and the apatite was the only source of $\mathrm{P}$.

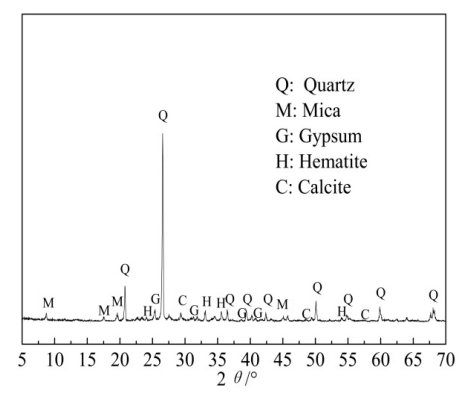

Figure 1. X-ray diffraction (XRD) pattern for roasted stone coal. 


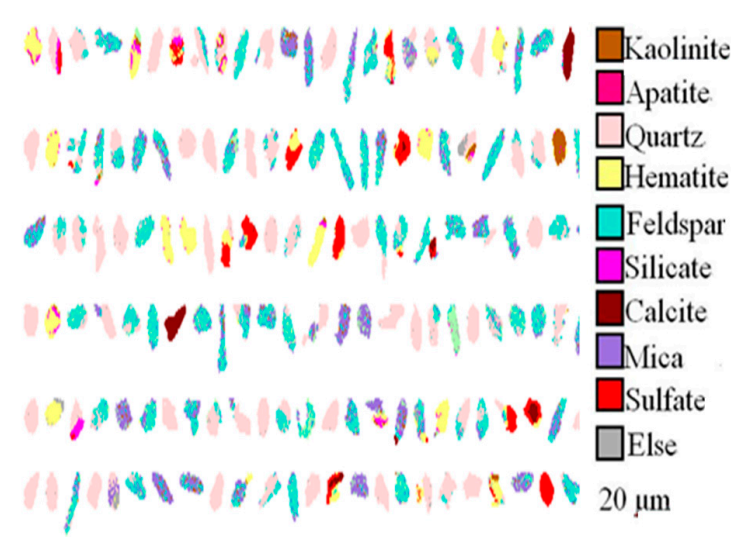

Figure 2. Quantitative evaluation of minerals by scanning electron microscopy (QEMSCAN) analysis result for the stone coal roasted residue.

Table 1. Main chemical composition of the stone coal roasted residue (wt \%).

\begin{tabular}{cccccccccc}
\hline Element & $\mathrm{SiO}_{2}$ & $\mathrm{CaO}$ & $\mathrm{Al}_{2} \mathrm{O}_{3}$ & $\mathrm{~V}_{\mathbf{2}} \mathrm{O}_{5}$ & $\mathrm{Fe}_{2} \mathrm{O}_{3}$ & $\mathrm{~K}_{2} \mathrm{O}$ & $\mathrm{Na}_{2} \mathrm{O}$ & $\mathbf{M g O}$ & $\mathbf{P}_{2} \mathrm{O}_{5}$ \\
\hline Content & 66.0 & 5.29 & 9.81 & 0.83 & 4.96 & 2.51 & 0.30 & 1.67 & 1.03 \\
\hline
\end{tabular}

All the reagents used in this study were of analytical reagent grade and the water used was distilled water.

\subsection{Experimental Procedure}

The experiments were preformed according to the flow sheet as show in Figure 3. According to our previous study, all of these tests were conducted at the liquid-to-solid ratio of $1.5 \mathrm{~mL} / \mathrm{g}$ (the volume/mass ratio of dilute sulfuric acid to raw ore) for $120 \mathrm{~min}$ [16].

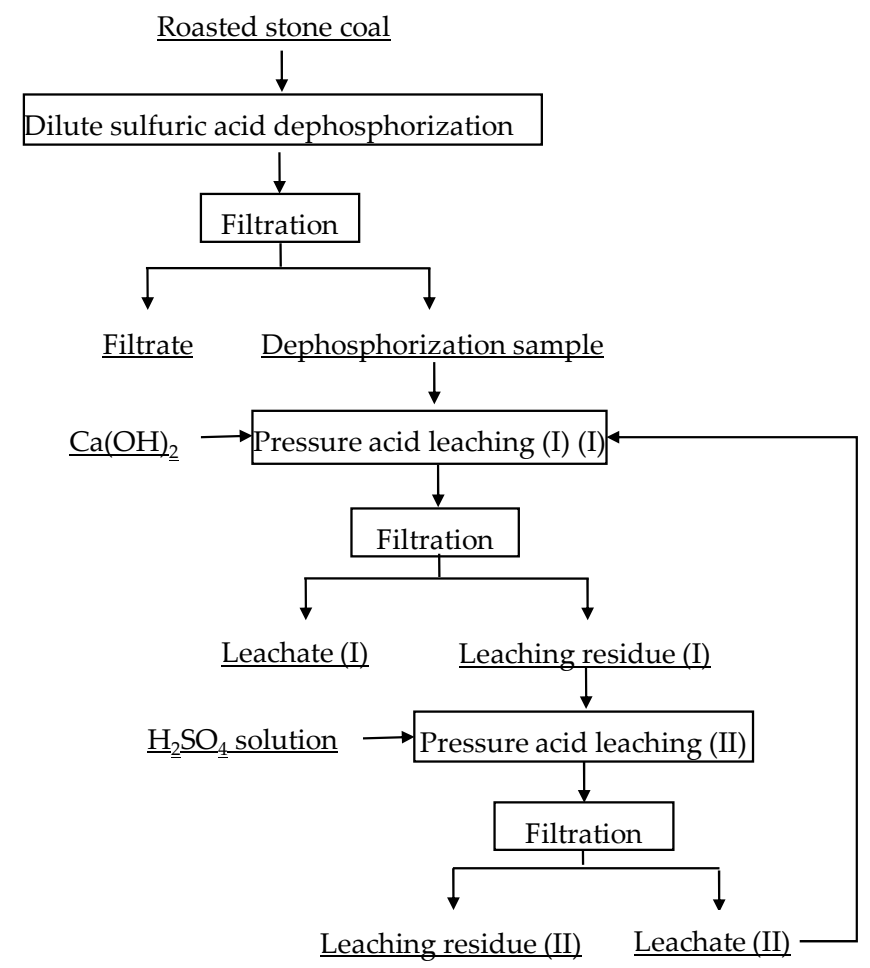

Figure 3. Flow sheet of the dilute sulfuric acid dephosphorization (DSAD)-two-stage pressure acid leaching (PAL) process. 


\subsubsection{DSAD Test}

In order to achieve the effective separation of $\mathrm{V}$ from $\mathrm{P}$, the DSAD tests were conducted. In this process the roasted stone coal was leached in a SZCL-2A magnetic and controlling temperature stirrer (Wuhan Keer Instrument Company, Wuhan, China). The sulfuric acid concentration was $1.0 \%(v / v)$, $1.5 \%(v / v), 2.0 \%(v / v), 2.5 \%(v / v), 3.0 \%(v / v), 3.5 \%(v / v)$ and $4.0 \%(v / v)$ and the temperature was controlled at 20, 40, 60, 80 and $100{ }^{\circ} \mathrm{C}$. After DSAD process, the slurries were filtrated by SHB-III vacuum suction filter device (Wuhan Keer Instrument Company, Wuhan, China). Then the contents of $\mathrm{V}$ and $\mathrm{P}$ in filtrate were analyzed.

\subsubsection{Two-Stage PAL Test}

For achieving the effective separation of $\mathrm{V}$ from $\mathrm{Fe}$ and $\mathrm{Al}$, the two-stage PAL tests were carried out.

In the first-stage PAL process the dephosphorization sample was leached by leachate (II) in a GSH-2 autoclave (Weihai Shandong Chaoyang Chemical Machinery Co., Ltd., Weihai, China) at the liquid-to-solid ratio of $1.5 \mathrm{~mL} / \mathrm{g}$, the leaching time of $120 \mathrm{~min}$ and the total pressure of $1.0 \mathrm{MPa}$. The first-stage sulfuric acid concentration was adjusted to $2.50 \%(v / v), 3.75 \%(v / v), 4.50 \%(v / v), 6.00 \%$ $(v / v), 7.50 \%(v / v)$ by adding $\mathrm{Ca}(\mathrm{OH})_{2}$ and the temperature was controlled at $90,120,150,180$ and $210{ }^{\circ} \mathrm{C}$, respectively. After the first-stage PAL the slurries were filtrated and then the contents of $\mathrm{V}$, $\mathrm{Fe}, \mathrm{Al}$ and $\mathrm{P}$ in leachate (I) were analyzed. Leaching residue (I) was leached by $\mathrm{H}_{2} \mathrm{SO}_{4}$ solution in the second-stage PAL process which was performed in a GSH-2 autoclave (Weihai Shandong Chaoyang Chemical Machinery Co., Ltd., Weihai, China) at the liquid-to-solid ratio of $1.5 \mathrm{~mL} / \mathrm{g}$, the leaching time of $120 \mathrm{~min}$ and the total pressure of $1.0 \mathrm{MPa}$. In this process, the second-stage sulfuric acid concentration was $7.5 \%(v / v), 10.0 \%(v / v), 12.5 \%(v / v), 15 \%(v / v), 17.5 \%(v / v)$ and $20.0 \%(v / v)$, and the temperature was controlled at $90,120,150,180$ and $210{ }^{\circ} \mathrm{C}$, respectively. After the second-stage PAL the slurries were filtrated. The leachate (II) was returned to the first-stage leaching for utilizing the residual sulfuric acid. After recycling the leachate (II) seven times the equilibrium result was obtained.

\subsection{Analysis Methods}

(1) The determination of vanadium content was measured in accordance with Test Methods of Vanadium in Coal Standard (GB/T 19226-2003) [16]. Other elements in this study were analyzed by using ICP-AES method which was conducted by an inductively coupled plasma-atomic emission spectrometer (Thermo Scientific) Advantage ER/S inductively coupled plasma-optical emission spectrometer (Thermo Scientific).

(2) The residual sulfuric acid concentration in leachate was determined by titration using $0.1 \mathrm{~mol} / \mathrm{L}$ $\mathrm{Na}_{2} \mathrm{CO}_{3}$ solution with methyl orange as an indicator [17].

(3) XRD analysis was conducted by an Xpertpro X-ray diffractometer (D/MAX 2500PC, Rigaku, Tokyo, Japan) with $\mathrm{Cu}-\mathrm{K} \alpha$ radiation, voltage $40 \mathrm{kV}$, current $30 \mathrm{~mA}$ and at the scanning rate of $15^{\circ} \cdot \mathrm{min}^{-1}$ from $5^{\circ}$ to $70^{\circ}$.

(4) Detailed mineralogy on the roasted stone coal was done using quantitative evaluation of minerals by QEMSCAN analysis which was conducted by the QEMSCAN analysis system (FEI).

(5) The chemical species was analyzed by using a VG Multilab $2000 \mathrm{X}$-ray photoelectron spectrometer (Thermo Scientific) and an Al-K $\alpha$ X-ray source with a solution of $0.47 \mathrm{eV}$.

\section{Results and Discussion}

\subsection{The DSAD-Two-Stage PAL Result}

\subsubsection{DSAD Result}

Figure 4a reported the dephosphorization efficiency and the vanadium loss obtained by varying sulfuric acid concentration. It can be seen that the dephosphorization efficiency apparently increased 
to $98.75 \%$ with the sulfuric acid concentration increased to $3.0 \%(v / v)$. Further increase of the sulfuric acid concentration had only a slight effect on dephosphorization efficiency. Hence, the sulfuric acid concentration should be $3.0 \%(v / v)$.
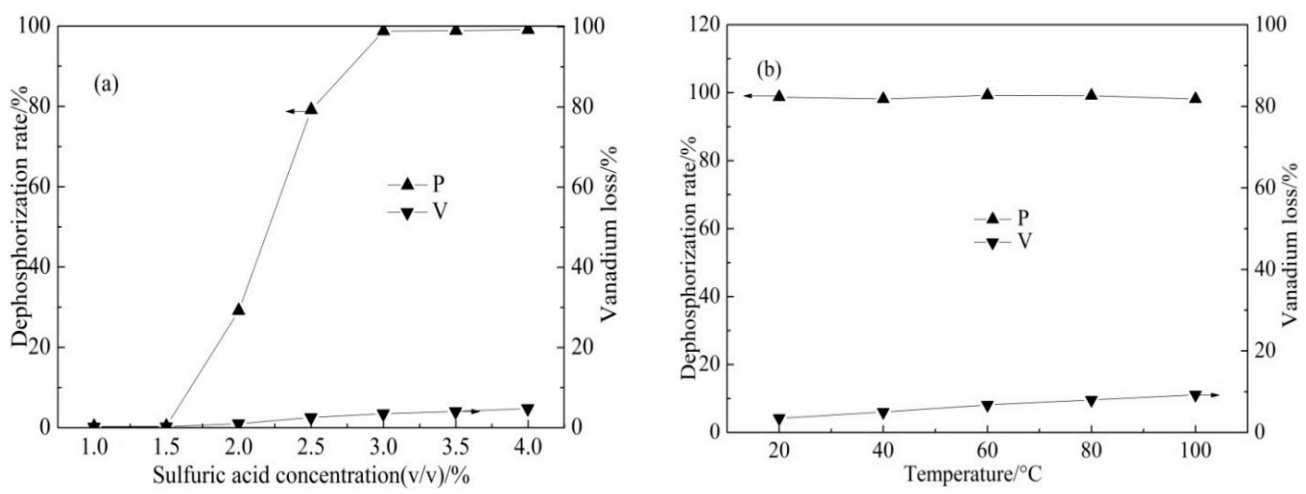

Figure 4. Effects of sulfuric acid concentration (a); and temperature (b) on the dephosphorization rate and the vanadium loss rate.

The effect of temperature on dephosphorization efficiency and vanadium loss were studied. The results (Figure $4 \mathrm{~b}$ ) showed that the vanadium loss increased from $3.52 \%$ to $9.25 \%$ with the increase of the temperature from 20 to $100{ }^{\circ} \mathrm{C}$. However, the dephosphorization efficiency changed a little with the increase of the temperature. So the temperature was controlled at $20^{\circ} \mathrm{C}$ in this study.

As discussed above, under these conditions that the temperature of $20{ }^{\circ} \mathrm{C}$, the sulfuric acid concentration of $3.0 \%(v / v)$, the liquid/solid ratio of $1.5 \mathrm{~mL} / \mathrm{g}$, and the time of $120 \mathrm{~min}$, the dephosphorization rate could reach $98.75 \%$ and the vanadium loss was just $3.52 \%$, the dephosphorization effect was significant.

\subsubsection{Pressure Acid Leaching (I) Result}

According to the research of Rubisov [18], the higher the residual acid concentration in leachate, the more $\mathrm{Fe}$ and $\mathrm{Al}$ could be leached under these PAL conditions. Thus, the $\mathrm{Ca}(\mathrm{OH})_{2}$ was added into pressure acid leaching (I) to decrease the residual sulfuric acid concentration of leachate (I). It was showed that both the residual sulfuric acid concentration and the leaching efficiency of $\mathrm{Fe}$ and $\mathrm{Al}$ decreased with the decrease of the initial sulfuric acid concentration of the first stage (Figure 5a). However, there was a sharp decrease in the leaching efficiency of $\mathrm{V}$ from $80.46 \%$ to $66.76 \%$ with the decrease in the first-stage initial sulfuric acid concentration from $3.75 \%(v / v)$ to $2.5 \%(v / v)$. Therefore, the optimum initial sulfuric acid concentration of the first stage was determined as $3.75 \%(v / v)$.
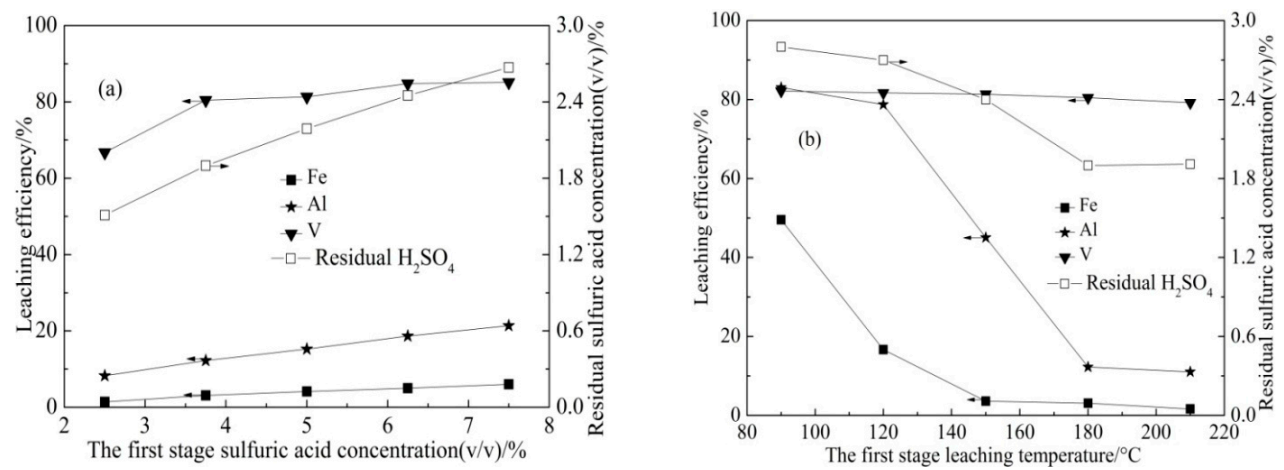

Figure 5. Effects of the acid pressure leaching (I) parameters on leaching efficiency of $\mathrm{V}, \mathrm{Al}, \mathrm{P}, \mathrm{Fe}$. (a) The initial sulfuric acid concentration of the first stage; (b) the leaching temperature of the first stage. 
Figure 5b showed that the leaching efficiency of Fe and Al decreased sharply with the increase of the leaching temperature of the first stage from 90 to $180{ }^{\circ} \mathrm{C}$. When the temperature was over $180^{\circ} \mathrm{C}$, the leaching efficiency of $\mathrm{Fe}, \mathrm{Al}$ and $\mathrm{V}$ remains unchanged. Therefore, the first-stage leaching temperature was recommended as $180{ }^{\circ} \mathrm{C}$ and the leaching efficiency of $\mathrm{V}, \mathrm{Fe}$ and $\mathrm{Al}$ was obtained as $80.46 \%, 3.12 \%$ and $12.24 \%$, respectively.

\subsubsection{Pressure Acid Leaching (II) Result}

It was indicated that the leaching efficiency of $\mathrm{V}$ increased with the increase of the second-stage sulfuric acid concentration. When sulfuric acid concentration of the second stage was over $15 \%(v / v)$, the leaching efficiency of V slowly increased (Figure 6a). Therefore, the second-stage sulfuric acid concentration of $15 \%(v / v)$ was utilized in this study.
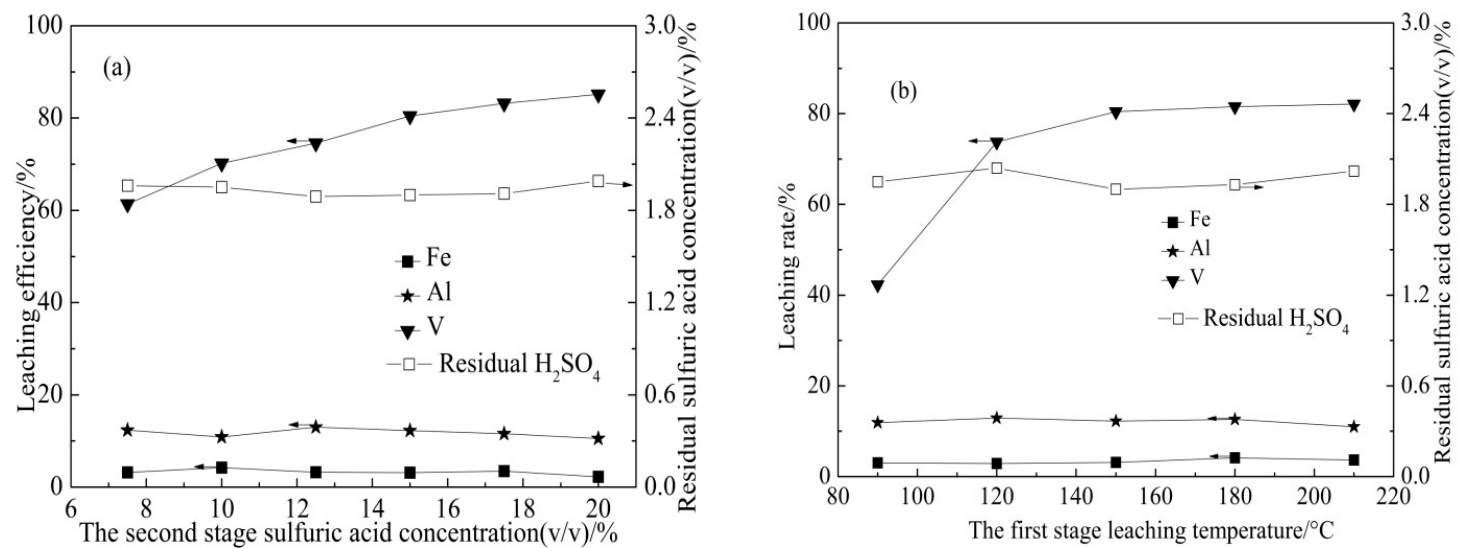

Figure 6. Effects of the acid pressure leaching (II) parameters on leaching efficiency of V, Al, P, Fe.

(a) The sulfuric acid concentration of the second stage; (b) the leaching temperature of the second stage.

It was shown that, by increasing the leaching temperature of the second stage from 90 to $150{ }^{\circ} \mathrm{C}$, the $\mathrm{V}$ leaching efficiency increased from $42.31 \%$ to $80.46 \%$. Upon further increase of the leaching temperature of the second stage, the leaching efficiency of $\mathrm{V}$, Fe and Al changed a little (Figure 6b). Thus, $150{ }^{\circ} \mathrm{C}$ was chosen as the optimal leaching temperature of the second stage in this study.

Therefore, the optimal conditions for the two-stage PAL were as follows: the liquid/solid ratio of $1.5 \mathrm{~mL} / \mathrm{g}$, the leaching time of $120 \mathrm{~min}$, the leaching pressure of $1.0 \mathrm{MPa}$, the first-stage initial sulfuric acid concentration of $3.75 \%(v / v)$, the first-stage leaching temperature of $180{ }^{\circ} \mathrm{C}$, the second-stage sulfuric acid concentration of $15 \%(v / v)$, the second-stage leaching temperature of $150{ }^{\circ} \mathrm{C}$. The leaching efficiency of $\mathrm{V}, \mathrm{Al}$ and $\mathrm{Fe}$ was $80.46 \%, 12.24 \%$ and $3.12 \%$, respectively. Under these conditions, the leaching efficiency of $\mathrm{P}$ was just $0.67 \%$ (Table 2). Compared to the conventional PAL (i) and (ii), both the residual $\mathrm{H}_{2} \mathrm{SO}_{4}$ concentration and the leaching efficiency of $\mathrm{Fe}, \mathrm{Al}$ and $\mathrm{P}$ has been significantly decreased (Table 2).

Table 2. Effect of leaching process on the residual $\mathrm{H}_{2} \mathrm{SO}_{4}$ concentration and leaching efficiencies of $\mathrm{V}$, $\mathrm{Fe}, \mathrm{Al}$ and $\mathrm{P}$ from the roasted stone coal (\%).

\begin{tabular}{cccccc}
\hline Process & V & Fe & Al & P & Residual $\mathbf{H}_{\mathbf{2}} \mathbf{S O}_{\mathbf{4}}(\boldsymbol{v} / \boldsymbol{v})$ \\
\hline a Conventional PAL (i) & 80.51 & 18.92 & 79.25 & 99.21 & 4.39 \\
b Conventional PAL (ii) & 82.13 & 19.96 & 60.48 & 98.20 & 4.29 \\
${ }^{c}$ DSAD-two-stage PAL & 80.46 & 3.12 & 12.24 & 0.67 & 1.90 \\
\hline
\end{tabular}

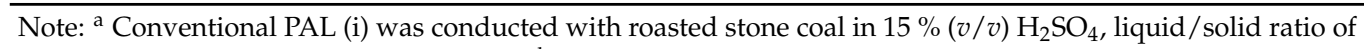
$1.5 \mathrm{~mL} / \mathrm{g}$ at $150{ }^{\circ} \mathrm{C}, 1.0 \mathrm{MPa}$ for $120 \mathrm{~min} ;{ }^{\mathrm{b}}$ Conventional PAL (ii) was conducted with roasted stone coal in $15 \%(v / v) \mathrm{H}_{2} \mathrm{SO}_{4}$, liquid/solid ratio of $1.5 \mathrm{~mL} / \mathrm{g}$ at $180{ }^{\circ} \mathrm{C}, 1.0 \mathrm{MPa}$ for $120 \mathrm{~min}$; ${ }^{\mathrm{c}}$ DSAD-two-stage PAL was conducted with roasted stone coal under the optimum conditions. 


\subsection{Analysis of Leaching Residue and Leachate}

In order to investigate the main reactions of $\mathrm{Fe}, \mathrm{Al}$ and $\mathrm{P}$ species in these processes, each stage residue was analyzed by XRD (Figure 7) and each stage filtrate was analyzed by ICP-AES (Table 3).

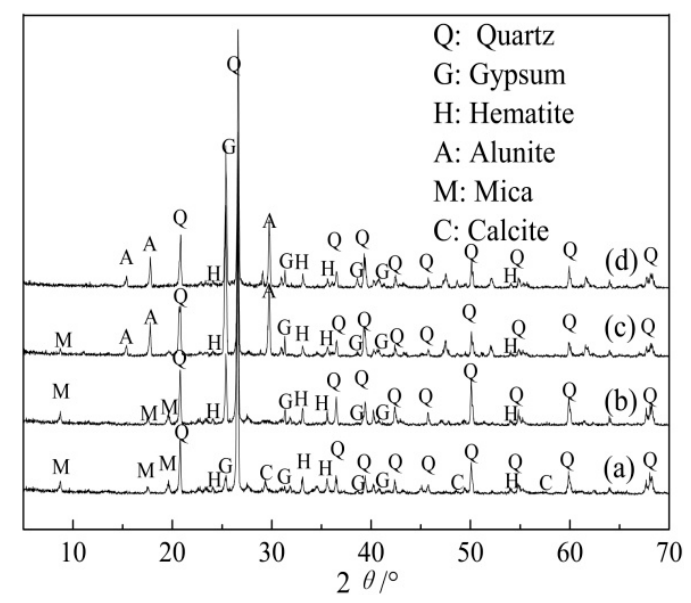

Figure 7. The XRD patterns for roasted stone coal (a); dephosphorization sample (b); leaching residue (I) (c); and leaching residue (II) (d).

Table 3. Content of $\mathrm{V}, \mathrm{Fe}, \mathrm{Al}$ and $\mathrm{P}$ for each stage filtrate $(\mathrm{mg} / \mathrm{L})$.

\begin{tabular}{ccccc}
\hline Each Stage Filtrate & $\mathbf{V}$ & Fe & Al & P \\
\hline Filtrate & 94 & 58 & 120 & 2864 \\
Leachate (I) & 2163 & 623 & 3672 & 19 \\
Leachate (II) & 1487 & 10019 & 20532 & 22 \\
\hline
\end{tabular}

Compared with the intensity of mica peaks of roasted stone coal (curve (a) in Figure 7), the intensity of mica peaks of dephosphorization sample (curve (b) in Figure 7) had almost no changes, indicating that the mica has almost not dissolved in the DSAD process, which resulted in the low vanadium loss (Figure 4).

The XRD analysis of leaching residue (I) (curve (c) in Figure 7) showed that the peaks of alunite appeared in the first-stage PAL process. Accordingly, the content of $\mathrm{Al}$ in leachate decreased from 20,532 to $3672 \mathrm{mg} / \mathrm{L}$ (Table 3). These phenomena show that the alunite formed by Al hydrolysis was the controlling solid balancing of Al concentration in leachate (I). According to the research of Rubisov [18], increasing reaction temperature or decreasing residual acidity could promote the hydrolysis of $\mathrm{Al}$ at these PAL conditions with the result that lower leaching efficiency of $\mathrm{Al}$ was obtained (Figure 5).

It was indicated that the residual mica of leaching residue (I) completely dissolved in the second-stage PAL process (curve (c) and (d) in Figure 7), which was the key to realizing the effective leaching of V. According to the study of Li [5], increasing leaching temperature and acidity could promote the dissolution of mica, which resulted in the increase of vanadium leaching efficiency (Figure 6).

In order to further reveal the main reactions of $\mathrm{Fe}, \mathrm{Al}$ and $\mathrm{P}$ species in these processes from the surface chemistry perspective, the XPS analysis was conducted in the binding energy regions of $\mathrm{P} 2 \mathrm{p}$, Ca $2 p, F e 2 p$ and Al 2p (Figure 8). 

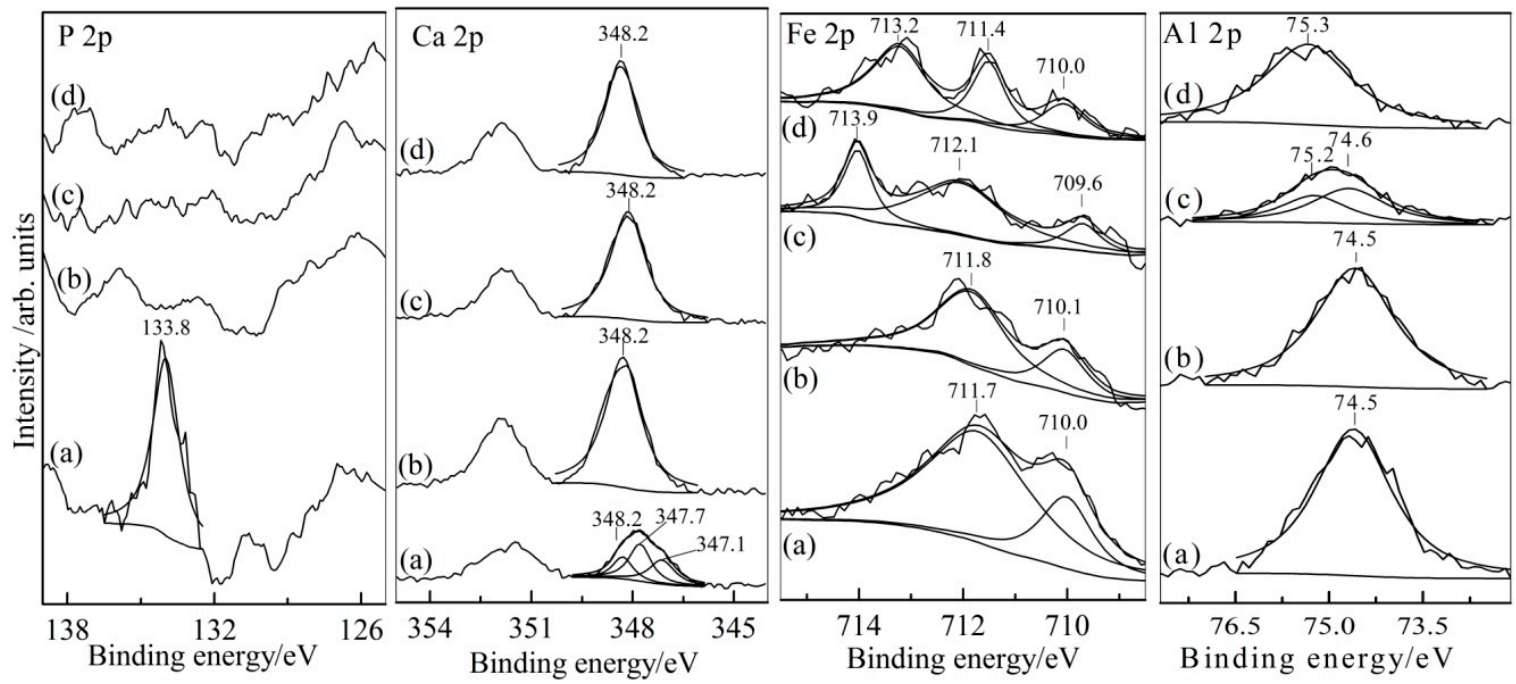

Figure 8. X-ray photoelectron $\mathrm{P} 2 \mathrm{p}, \mathrm{Ca} 2 \mathrm{p}, \mathrm{Fe} 2 \mathrm{p}$ and $\mathrm{Al} 2 \mathrm{p}$ spectra from roasted stone coal (a); dephosphorization sample (b); leaching residue (I) (c); and leaching residue (II) (d).

The P $2 p$ spectrum could be fitted to the peak at $133.8 \mathrm{eV}$, which was the characteristic of pentavalent phosphorous in $\mathrm{PO}_{4}$ tetrahedra (curve (a) in Figure 8) [19]. The raw Ca 2p spectrum was composed of three fitted curves. The binding energy at 347.1, 347.7 and $348.2 \mathrm{eV}$ was the XPS peaks of Ca $2 p_{3 / 2}$ for calcite, apatite and gypsum, respectively (curve (a) in Figure 8) [20-22]. After DSAD, the peaks at $133.8,347.1$ and $347.7 \mathrm{eV}$ disappeared. However, the peak at $348.2 \mathrm{eV}$ became stronger, which suggested that the apatite and calcite had already completely reacted with sulfuric acid in the DSAD process. This was the key to achieving the high dephosphorization rate.

The Fe 2p XPS spectrums in Figure 8a-d showed two peaks near 711.7 and $710.0 \mathrm{eV}$ corresponding to hematite and magnetite [23], respectively. After the first-stage PAL, a new peak around $713.6 \mathrm{eV}$ corresponding to $\mathrm{Fe} 2 \mathrm{p}_{3 / 2}$ for $\mathrm{Fe}-\mathrm{SO}_{4}$ appeared [24,25]. It was suggested that a new kind of iron-sulphate compound generated, which resulted in the decrease of Fe concentration from 10,019 to $623 \mathrm{mg} / \mathrm{L}$ (Table 3). According to the recent published paper [26], this iron-sulphate compound generated by Fe hydrolyzation was probably the schwertmannite $\mathrm{Fe}_{8} \mathrm{O}_{8}(\mathrm{OH})_{6} \mathrm{SO}_{4}$, a jarosite precursor phase, and increasing reaction temperature or decreasing residual acidity could promote the formation of schwertmannite, which resulted in the lower leaching efficiency of Fe (Figure 5). After the first-stage PAL, the peaks' intensity of hematite became smaller (curve (b) and (c) in Figure 7). It was suggested that the hematite partly dissolved. The generation of iron-sulphate compound and the dissolution of hematite in the first-stage PAL process indicated that the formation of iron-sulphate compound by Fe hydrolyzation could be initiated more easily than that of hematite under these pressure acid leaching conditions, because the strong binding anions like $\mathrm{SO}_{4}{ }^{2-}$ could favor the formation of this iron-sulphate compound [27].

The Al 2p XPS peak centered at $74.5 \mathrm{eV}$ assigned to mica [28] had almost no change in the DSAD process (curve (a) and curve (b) in Figure 8). It is suggested that the mica structure has not been destroyed. After the first-stage PAL, another peak centered at $75.3 \mathrm{eV}$ assigned to $\mathrm{Al}-\mathrm{SO}_{4}$ bonds [29] appeared. This phenomenon was consistent with the generation of alunite (curve (b) and (c) in Figure 7). After the second-stage PAL, the peak of mica disappeared, which suggested that the mica has completely dissolved, which was in accordance with the XRD analysis result (curve (c) and (d) in Figure 7). The presence of alunite and the absence of mica reflected that the alunite was more difficult to leach than mica. 


\subsection{Thermodynamics Analysis}

In order to achieve a better understanding of the principles of selective leaching of $\mathrm{V}$ from roasted stone coal by DSAD-two-stage PAL, thermodynamics was applied into the analysis. As discussed above, it was inferred that the possible main equilibrium reactions in these processes could be described as Equations (1)-(20) in Table 4. The Equations (21)-(29) were equilibrium reactions of the species involved in Equations (1)-(20) [30]. All of these equilibrium reactions could be expressed as Formula (1).

$$
a \mathrm{~A}+n \mathrm{H}^{+}=b \mathrm{~B}+c \mathrm{H}_{2} \mathrm{O}
$$

Table 4. $\mathrm{pH}_{T}^{\Theta}$ of different equilibrium reactions at $373-473 \mathrm{~K}$.

\begin{tabular}{|c|c|c|c|c|c|c|}
\hline Number & Equilibrium Reaction & $\mathbf{p H}_{273}^{\ominus}$ & $\mathbf{p} \mathbf{H}_{323}^{\theta}$ & $\mathbf{p} \mathbf{H}_{373}^{\ominus}$ & $\mathbf{p H}_{423}^{\Theta}$ & $\mathbf{p H}_{473}^{\Theta}$ \\
\hline 1 & $\mathrm{CaCO}_{3}+\mathrm{HSO}_{4}^{-}+\mathrm{H}^{+}=\mathrm{CO}_{2} \uparrow+\mathrm{CaSO}_{4} \downarrow+\mathrm{H}_{2} \mathrm{O}$ & 13.23 & 12.53 & 12.14 & 11.95 & 11.91 \\
\hline 2 & $\mathrm{CaCO}_{3}+\mathrm{SO}_{4}{ }^{2-}+2 \mathrm{H}^{+}=\mathrm{CO}_{2} \uparrow+\mathrm{CaSO}_{4} \downarrow+\mathrm{H}_{2} \mathrm{O}$ & 7.43 & 7.40 & 7.58 & 7.87 & 8.25 \\
\hline 3 & $\mathrm{CaCO}_{3}+\mathrm{SO}_{4}^{2-}+\mathrm{H}^{+}=\mathrm{CaSO}_{4} \downarrow+\mathrm{HCO}_{3}^{-}$ & 7.17 & 6.81 & 6.79 & 6.95 & 7.26 \\
\hline 4 & $\mathrm{Fe}_{2} \mathrm{O}_{3}+6 \mathrm{H}^{+}=2 \mathrm{Fe}^{3+}+3 \mathrm{H}_{2} \mathrm{O}$ & 0.49 & -0.16 & -0.65 & -1.03 & -1.36 \\
\hline 5 & $\mathrm{KAl}_{2}\left(\mathrm{AlSi}_{3} \mathrm{O}_{10}\right)(\mathrm{OH})_{2}+10 \mathrm{H}^{+}=3 \mathrm{Al}^{3+}+\mathrm{K}^{+}+3 \mathrm{H}_{4} \mathrm{SiO}_{4}$ & 2.20 & 1.35 & 0.72 & 0.22 & -0.20 \\
\hline 6 & $\mathrm{KAl}_{2}\left(\mathrm{AlSi}_{3} \mathrm{O}_{10}\right)(\mathrm{OH})_{2}+7 \mathrm{H}^{+}=3 \mathrm{Al}^{3+}+\mathrm{K}^{+}+3 \mathrm{HSiO}_{3}^{-}+3 \mathrm{H}_{2} \mathrm{O}$ & -1.90 & -2.65 & -3.30 & -3.89 & -4.46 \\
\hline 8 & $\mathrm{KAl}_{3}\left(\mathrm{SO}_{4}\right)_{2}(\mathrm{OH})_{6}+6 \mathrm{H}^{+}=3 \mathrm{Al}^{3+}+6 \mathrm{H}_{2} \mathrm{O}+\mathrm{K}^{+}+2 \mathrm{SO}_{4}^{2-}$ & 0.89 & -0.24 & -1.29 & -2.25 & -3.18 \\
\hline 9 & $\mathrm{Ca}_{5}\left(\mathrm{PO}_{4}\right)_{3} \mathrm{~F}+2 \mathrm{H}^{+}+5 \mathrm{HSO}_{4}^{-}=5 \mathrm{CaSO}_{4} \downarrow+3 \mathrm{H}_{2} \mathrm{PO}_{4}^{-}+\mathrm{HF}$ & 6.88 & 5.22 & 3.99 & 3.05 & 2.34 \\
\hline 10 & $\mathrm{Ca}_{5}\left(\mathrm{PO}_{4}\right)_{3} \mathrm{~F}+5 \mathrm{H}^{+}+5 \mathrm{HSO}_{4}^{-}=5 \mathrm{CaSO}_{4} \downarrow+3 \mathrm{H}_{3} \mathrm{PO}_{4}+\mathrm{HF}$ & 0.63 & 0.41 & 0.50 & 0.67 & 0.92 \\
\hline 11 & $\mathrm{Ca}_{5}\left(\mathrm{PO}_{4}\right)_{3} \mathrm{~F}+\mathrm{H}^{+}+5 \mathrm{SO}_{4}{ }^{2-}=5 \mathrm{CaSO}_{4} \downarrow+3 \mathrm{PO}_{4}{ }^{3-}+\mathrm{HF}$ & -37.99 & -36.35 & -35.16 & -34.29 & -33.67 \\
\hline 12 & $\mathrm{Ca}_{5}\left(\mathrm{PO}_{4}\right)_{3} \mathrm{~F}+4 \mathrm{H}^{+}+5 \mathrm{SO}_{4}{ }^{2-}=5 \mathrm{CaSO}_{4} \downarrow+3 \mathrm{HPO}_{4}{ }^{2-}+\mathrm{HF}$ & -0.02 & 0.05 & 0.28 & 0.58 & 0.94 \\
\hline 13 & $\mathrm{Ca}_{5}\left(\mathrm{PO}_{4}\right)_{3} \mathrm{~F}+7 \mathrm{H}^{+}+5 \mathrm{SO}_{4}^{2-}=5 \mathrm{CaSO}_{4} \downarrow+3 \mathrm{H}_{2} \mathrm{PO}_{4}^{-}+\mathrm{HF}$ & 3.13 & 3.11 & 3.30 & 3.58 & 3.95 \\
\hline 14 & $\mathrm{Ca}_{5}\left(\mathrm{PO}_{4}\right)_{3} \mathrm{~F}+10 \mathrm{H}^{+}+5 \mathrm{SO}_{4}^{2-}=5 \mathrm{CaSO}_{4} \downarrow+3 \mathrm{H}_{3} \mathrm{PO}_{4}+\mathrm{HF}$ & 1.13 & 1.34 & 1.76 & 2.23 & 2.75 \\
\hline 15 & $\mathrm{Ca}_{5}\left(\mathrm{PO}_{4}\right)_{3} \mathrm{~F}+\mathrm{H}^{+}+5 \mathrm{HSO}_{4}^{-}=5 \mathrm{CaSO}_{4} \downarrow+3 \mathrm{H}_{2} \mathrm{PO}_{4}^{-}+\mathrm{F}^{-}$ & 10.79 & 7.12 & 4.28 & 2.03 & 0.21 \\
\hline 16 & $\mathrm{Ca}_{5}\left(\mathrm{PO}_{4}\right)_{3} \mathrm{~F}+4 \mathrm{H}^{+}+5 \mathrm{HSO}_{4}^{-}=5 \mathrm{CaSO}_{4} \downarrow+3 \mathrm{H}_{3} \mathrm{PO}_{4}+\mathrm{F}^{-}$ & 0.04 & -0.32 & -0.30 & -0.18 & 0.03 \\
\hline 17 & $\mathrm{Ca}_{5}\left(\mathrm{PO}_{4}\right)_{3} \mathrm{~F}+3 \mathrm{H}^{+}+5 \mathrm{SO}_{4}{ }^{2-}=5 \mathrm{CaSO}_{4} \downarrow+3 \mathrm{HPO}_{4}{ }^{2-}+\mathrm{F}^{-}$ & -1.02 & -1.04 & -0.86 & -0.58 & -0.24 \\
\hline 18 & $\mathrm{Ca}_{5}\left(\mathrm{PO}_{4}\right)_{3} \mathrm{~F}+6 \mathrm{H}^{+}+5 \mathrm{SO}_{4}{ }^{2-}=5 \mathrm{CaSO}_{4} \downarrow+3 \mathrm{H}_{2} \mathrm{PO}_{4}^{-}+\mathrm{F}^{-}$ & 6.30 & 6.16 & 6.46 & 6.99 & 7.71 \\
\hline 19 & $\mathrm{Ca}_{5}\left(\mathrm{PO}_{4}\right)_{3} \mathrm{~F}+9 \mathrm{H}^{+}+5 \mathrm{SO}_{4}{ }^{2-}=5 \mathrm{CaSO}_{4} \downarrow+3 \mathrm{H}_{3} \mathrm{PO}_{4}+\mathrm{F}^{-}$ & 0.92 & 1.12 & 1.54 & 2.02 & 2.56 \\
\hline 20 & $\mathrm{~V}_{2} \mathrm{O}_{4}+4 \mathrm{H}^{+}=2 \mathrm{VO}^{2+}+2 \mathrm{H}_{2} \mathrm{O}$ & 2.62 & 1.74 & 1.14 & 0.70 & 0.36 \\
\hline 21 & $\mathrm{SO}_{4}^{2-}+\mathrm{H}^{+}=\mathrm{HSO}_{4}^{-}$ & 1.62 & 2.27 & 3.02 & 3.79 & 4.59 \\
\hline 22 & $\mathrm{HSiO}_{3}{ }^{-}+\mathrm{H}^{+}+\mathrm{H}_{2} \mathrm{O}=\mathrm{H}_{4} \mathrm{SiO}_{4}$ & 11.80 & 10.69 & 10.10 & 9.82 & 9.76 \\
\hline 23 & $\mathrm{SiO}_{4}^{4-}+3 \mathrm{H}^{+}=\mathrm{HSiO}_{3}^{-}+\mathrm{H}_{2} \mathrm{O}$ & 13.68 & 12.90 & 12.72 & 12.95 & 13.43 \\
\hline 24 & $\mathrm{HCO}_{3}{ }^{-}+\mathrm{H}^{+}=\mathrm{CO}_{2} \uparrow+\mathrm{H}_{2} \mathrm{O}$ & 7.68 & 7.99 & 8.36 & 8.78 & 9.24 \\
\hline 25 & $\mathrm{CO}_{3}^{2-}+\mathrm{H}^{+}=\mathrm{HCO}_{3}^{-}$ & 10.62 & 10.17 & 10.09 & 10.22 & 10.51 \\
\hline 26 & $\mathrm{~F}^{-}+\mathrm{H}^{+}=\mathrm{HF}$ & 2.98 & 3.33 & 3.70 & 4.07 & 4.48 \\
\hline 27 & $\mathrm{H}_{2} \mathrm{PO}_{4}^{-}+\mathrm{H}^{+}=\mathrm{H}_{3} \mathrm{PO}_{4}$ & -3.54 & -2.80 & -1.83 & -0.92 & -0.04 \\
\hline 28 & $\mathrm{HPO}_{4}{ }^{2-}+\mathrm{H}^{+}=\mathrm{H}_{2} \mathrm{PO}_{4}{ }^{-}$ & 7.32 & 7.19 & 7.32 & 7.58 & 7.95 \\
\hline 29 & $\mathrm{PO}_{4}{ }^{3-}+\mathrm{H}^{+}=\mathrm{HPO}_{4}{ }^{2-}$ & 12.64 & 12.19 & 12.09 & 12.21 & 12.48 \\
\hline
\end{tabular}

The Gibbs free energy change of reaction Formula (1) could be calculated as Formula (2).

$$
\Delta_{\mathrm{r}} G_{T}=\Delta_{\mathrm{r}} G_{T}^{\theta}+R T \ln \frac{a_{\mathrm{B}}^{b}}{a_{\mathrm{A}}^{a}}+2.303 n R T \mathrm{pH}_{T}
$$

For dissolving A, the Gibbs free energy change should satisfy that: $\Delta_{\mathrm{r}} G_{T} \leqslant 0$. Formula (2) could transform to Formula (3).

$$
\mathrm{pH}_{T} \leqslant \frac{-\Delta_{\mathrm{r}} G_{T}^{\Theta}}{2.303 n R T}+\frac{1}{n} \lg \frac{a_{\mathrm{B}}^{b}}{a_{\mathrm{A}}^{a}}
$$

For simplifying calculation, the activities of all species involved in the reactions have been considered to be 1, i.e., $a_{\mathrm{A}}=a_{\mathrm{B}}=1$. The Formula (3) could transform to Formula (4)

$$
\mathrm{pH}_{T} \leqslant \mathrm{pH}_{T}^{\theta}=\frac{-\Delta_{\mathrm{r}} G_{T}^{\theta}}{2.303 n R T}
$$

The Gibbs free energy data required at high temperature were obtained from the research of Yang [31], and then the $\mathrm{pH}_{T}^{\Theta}$ values of these reactions calculated (Table 4) as Formula (4) [32]. It was indicated that the lower the $\mathrm{pH}_{T}^{\ominus}$ values was, the easier the A could be leached. 
The theoretical equilibrium reactions of minerals in sulfuric acid solution were determined by the following methods: for the equation 1 in which $\mathrm{CO}_{2}$ and $\mathrm{HSO}_{4}{ }^{-}$involved, this equation should balance in the stable region of $\mathrm{CO}_{2}$ and $\mathrm{HSO}_{4}{ }^{-}$(according to the Equations (21)-(29), $\mathrm{CO}_{2}$ and $\mathrm{HSO}_{4}{ }^{-}$exist in the acid solution of $\mathrm{pH}<\mathrm{pH}_{T}^{\Theta}(24)$ and $\mathrm{pH}<\mathrm{pH}_{T}^{\Theta}(21)$, respectively), i.e., the $\mathrm{pH}_{T}^{\Theta}$ of Equation (1) should be lower than that of Equations (21) and (24). However, the calculated result was inconsistent with this (Table 4). Thus, Equation (1) was not the equilibrium reaction of calcite in sulfuric acid solution. With this method, the Equation (2) was determined as theoretical equilibrium reaction of calcite in sulfuric acid solution. Similarly, the theoretical equilibrium reactions of hematite, mica, alunite, apatite and $\mathrm{V}_{2} \mathrm{O}_{4}$ in sulfuric acid solution were determined as Equations (4), (5), (7), (18) and (20), respectively.

According to the calculated results of Equations (4), (5), (7), (18) and (20), the $\mathrm{pH}_{T}^{\Theta}$ value of these minerals were in this order: calcite $>$ apatite $>$ mica $>$ alunite $>$ hematite (Table 4 ). Therefore, the difficult degree sequences of leaching could be inferred as follows: hematite $>$ alunite $>$ mica $>$ apatite $>$ calcite. As apatite could be leached more easily than mica, the apatite could completely reacted with sulfuric acid while the mica almost has no change in the DSAD process which was the key to achieving the effective separation of $\mathrm{V}$ from $\mathrm{P}$. Table 4 also showed that the $\mathrm{pH}_{T}^{\Theta}$ value of $\mathrm{V}_{2} \mathrm{O}_{4}$ was higher than that of hematite and alunite, i.e., the difficult degree sequences of hydrolyzation could be inferred as follows: $\mathrm{V}_{2} \mathrm{O}_{4}>$ alunite $>$ hematite. According to the former analysis, the formation of the iron-sulphate compound by Fe hydrolyzation could be initiated more easily than that of hematite under these leaching conditions. Therefore, the conclusion could be obtained that the hydrolyzation of $\mathrm{Fe}$ and $\mathrm{Al}$ could be initiated more easily than that of $\mathrm{V}$ by decreasing the residual acid of leachate, which was the key to achieving the effective separation of $\mathrm{V}$ from Fe and Al. This explained very well that the $\mathrm{Fe}$ and $\mathrm{Al}$ concentration decreased greatly but the $\mathrm{V}$ concentration had not decreased after the first-stage PAL (Table 3).

\section{Conclusions}

From the results of this study, the following conclusions could be drawn:

(1) The selective leaching of vanadium from roasted stone coal could be realized by DSAD-two-stage PAL. The optimum DSAD conditions were: the temperature of $20^{\circ} \mathrm{C}$, the sulfuric acid concentration of $3.0 \%(v / v)$, the liquid/solid ratio of $1.5 \mathrm{~mL} / \mathrm{g}$ and the time of $120 \mathrm{~min}$. Under these DSAD conditions, the dephosphorization rate could reach $98.75 \%$, while the vanadium loss rate was just $3.52 \%$. After the DSAD, the effective separation of V from $\mathrm{P}$ was realized. Then the dephosphorization sample was treated by two-stage PAL with these conditions that the liquid/solid ratio of $1.5 \mathrm{~mL} / \mathrm{g}$, the leaching time of $120 \mathrm{~min}$, the leaching pressure of $1.0 \mathrm{MPa}$, the first-stage sulfuric acid concentration of $3.75 \%(v / v)$, the first-stage leaching temperature of $180{ }^{\circ} \mathrm{C}$, the second-stage sulfuric acid concentration of $15 \%(v / v)$, the second-stage leaching temperature of $150{ }^{\circ} \mathrm{C}$. The leaching efficiency of $\mathrm{V}, \mathrm{Al}, \mathrm{P}$, and $\mathrm{Fe}$ was $80.46 \%, 12.24 \%, 0.67 \%$ and $3.12 \%$, respectively. After the two-stage $\mathrm{PAL}$, the effective separation of $\mathrm{V}$ from $\mathrm{Al}$ and Fe was realized.

(2) The mechanisms of selective leaching of vanadium from roasted stone coal by DSAD-two-stage PAL could be described as follows: the apatite could be leached more easily than mica. Thus, the apatite could completely reacted with sulfuric acid while the mica almost had no change in the DSAD process, which was the key to achieving the effective separation of V from P. Similarly, as the hydrolyzation of $\mathrm{Fe}$ and $\mathrm{Al}$ could be initiated more easily than that of $\mathrm{V}$ by decreasing the residual acid of leachate, the alunite and the iron-sulphate compound were generated in the first-stage PAL process, which resulted in the effective separation of $\mathrm{V}$ from Fe and $\mathrm{Al}$.

Acknowledgments: This work is financially supported by National Natural Science Foundation of China (No. 51474162, No. 51404174) and the Research Project of Chinese Ministry of Education (No. 213025A).

Author Contributions: Jun Huang, Jing Huang and Yimin Zhang conceived and designed the experiments. Jun Huang and Nannan Xue prepared the samples and performed the experiments. Jun Huang, Zhenlei Cai and 
Jing Huang analyzed the data. Jun Huang, Yimin Zhang, Jing Huang and Tao Liu contributed to the writing and revising of the paper.

Conflicts of Interest: The authors declare no conflict of interest.

\section{References}

1. Zhang, Y.M.; Bao, S.X.; Liu, T.; Chen, T.J.; Huang, J. The technology of extracting vanadium from stone coal in China: History, current status and future prospects. Hydrometallurgy 2011, 109, 116-124. [CrossRef]

2. Cai, Z.L.; Zhang, Y.M.; Liu, T.; Huang, J. Mechanisms of vanadium recovery from stone coal by novel $\mathrm{BaCO}_{3} / \mathrm{CaO}$ composite additive roasting and acid leaching technology. Minerals 2016, 6, 26. [CrossRef]

3. Wang, L.; Sun, W.; Liu, R.Q.; Gu, X.C. Flotation recovery of vanadium from low-grade stone coal. Trans. Nonferrous Met. Soc. China 2014, 24, 1145-1151. [CrossRef]

4. Zhou, X.Y.; Li, C.L.; Li, J.; Liu, H.Z.; Wu, S.Y. Leaching of vanadium from carbonaceous shale. Hydrometallurgy 2009, 99, 97-99. [CrossRef]

5. Li, M.T.; Wei, C.; Qiu, S.; Zhou, X.J.; Li, C.X.; Deng, Z.G. Kinetics of vanadium dissolution from black shale in pressure acid leaching. Hydrometallurgy 2010, 104, 193-200. [CrossRef]

6. Li, X.B.; Wei, C.; Deng, Z.G.; Li, M.T.; Li, C.X.; Fan, G. Selective solvent extraction of vanadium over iron from stone coal/black shale acid leach solution by D2EHPA/TBP. Hydrometallurgy 2011, 105, 359-363. [CrossRef]

7. Ma, Y.Q.; Wang, X.W.; Wang, M.Y.; Jiang, C.J.; Xiang, X.Y.; Zhang, X.L. Separation of V(IV) and Fe(III) from the acid leach solution of stone coal by D2EHPA/TBP. Hydrometallurgy 2015, 153, 38-45. [CrossRef]

8. Li, W.; Zhang, Y.M.; Liu, T.; Huang, J.; Wang, Y. Comparison of ion exchange and solvent extraction in recovering vanadium from sulfuric acid leach solutions of stone coal. Hydrometallurgy 2013, 131-132, 1-7. [CrossRef]

9. Li, H.Y.; Wang, K.; Hua, W.H.; Yang, Z.; Zhou, W.; Xie, B. Selective leaching of vanadium in calcification-roasted vanadium slag by ammonium carbonate. Hydrometallurgy 2016, 160, 18-25. [CrossRef]

10. Xia, W.T.; Ren, Z.D.; Gao, Y.F. Removal of phosphorus from high phosphorus iron ores by selective $\mathrm{HCl}$ leaching method. J. Iron Steel Res. Int. 2011, 18, 1-4. [CrossRef]

11. Chen, C.Y.; Misra, V.N.; Clough, J.; Mun, R. Dephosphorisation of western Australian iron ore by hydrometallurgical process. Miner. Eng. 1999, 12, 1083-1092. [CrossRef]

12. Jin, Y.S.; Jiang, T.; Yang, Y.B.; Li, Q.; Li, G.H.; Guo, Y.F. Removal of phosphorus from iron ores by chemical leaching. J. Cent. South. Univ. Technol. 2006, 13, 673-677. [CrossRef]

13. Önal, M.A.R.; Topkaya, Y.A. Pressure acid leaching of Çaldağ lateritic nickel ore: An alternative to heap leaching. Hydrometallurgy 2014, 142, 98-107. [CrossRef]

14. Xu, B.; Zhong, H.; Jiang, T. Recovery of valuable metals from Gacun complex copper concentrate by two-stage countercurrent oxygen pressure acid leaching process. Miner. Eng. 2011, 24, 1082-1083. [CrossRef]

15. Zhang, Y.M.; Zhu, X.B.; Liu, T.; Huang, J.; Song, S.X. Effect of colloidal potassium alum formation on vanadium recovery from acid leach solutions of stone coal. Hydrometallurgy 2013, 13, 54-58. [CrossRef]

16. Huang, J.; Zhang, Y.M.; Huang, J.; Liu, T.; Xue, N.N. Study on Roasting-Pressure Acid Leaching of Vanadium from Stone Coal. Metal Mine 2015, 10, 85-89. (In Chinese)

17. Li, W.; Zhang, Y.M.; Huang, J.; Zhu, X.B.; Wang, Y. Separation and recovery of sulfuric acid from acidic vanadium leaching solution by diffusion dialysis. Sep. Purif. Technol. 2012, 96, 44-49. [CrossRef]

18. Rubisov, D.H.; Papangelakis, V.G. Sulphuric acid pressure leaching of laterites-speciation and prediction of metal solubilities "at temperature". Hydrometallurgy 2000, 58, 13-26. [CrossRef]

19. Glorieux, B.; Berjoan, R.; Matecki, M.; Kammouni, A.; Perarnau, D. XPS analyses of lanthanides phosphates. Appl. Surf. Sci. 2007, 253, 3349-3359. [CrossRef]

20. Cai, Y.H.; Pan, Y.G.; Xue, J.Y.; Sun, Q.F.; Su, G.Z.; Li, X. Comparative XPS study between experimentally and naturally weathered pyrites. Appl. Surf. Sci. 2009, 255, 8750-8760. [CrossRef]

21. Deng, M.J.; Liu, Q.X.; Xu, Z.H. Impact of gypsum supersaturated solution on surface properties of silica and sphalerite minerals. Miner. Eng. 2013, 46-47, 6-15. [CrossRef]

22. Kačiulis, S.; Mattogno, G.; Pandolfi, L.; Cavalli, M.; Gnappi, G.; Montenero, A. XPS study of apatite-based coatings prepared by sol-gel technique. Appl. Surf. Sci. 1999, 151,1-5. [CrossRef]

23. Du, J.K.; Bao, J.G.; Fu, X.Y.; Lu, C.H.; Kim, S.H. Mesoporous sulfur-modified iron oxide as an effective Fenton-like catalyst for degradation of bisphenol A. Appl. Catal. B Environ. 2016, 184, 132-141. [CrossRef] 
24. Yang, X.; Zhu, M.Y.; Kang, F.F.; Cao, S.S.; Chen, R.F.; Liu, H.; Wei, Y. Formation mechanism of a series of trigonal antiprismatic jarosite-type compounds. J. Cryst. Growth 2015, 429, 49-55. [CrossRef]

25. Khoshkhoo, M.; Dopson, M.; Shchukarev, A.; Sandström, Å. Chalcopyrite leaching and bioleaching: An X-ray photoelectron spectroscopic (XPS) investigation on the nature of hindered dissolution. Hydrometallurgy 2014, 149, 220-227. [CrossRef]

26. Klauber, C. A critical review of the surface chemistry of acidic ferric sulphate dissolution of chalcopyrite with regards to hindered dissolution. Int. J. Miner. Process. 2008, 86, 1-17. [CrossRef]

27. Zhu, M.Q.; Legg, B.; Zhang, H.Z.; Gilbert, B.; Yang, R.; Banfield, J.; Waychunas, G.A. Early-stage formation of iron oxyhydroxides during neutralization of simulated acid mine drainage solutions. Environ. Sci. Technol. 2012, 46, 8140-8147. [CrossRef] [PubMed]

28. Liu, Z.H.; Brown, N.M.D.; McKinley, A. Characterisation of oxygen plasma-modified mica surfaces using XPS and AFM. Appl. Surf. Sci. 1997, 108, 319-332. [CrossRef]

29. Lim, V.W.L.; Lia, S.; Kanga, E.T.; Neoha, K.G.; Tanb, K.L. In situ XPS study of thermally deposited aluminium on chemically synthesized polypyrrole films. Synth. Met. 1999, 106, 1-11. [CrossRef]

30. Parsons, R. Atlas of Electrochemical Equilibria in Aqueous Solutions: By Marcel Pourbaix, 2nd ed.; Pergamon Press: Oxford, UK, 1966; pp. 234-626.

31. Yang, X.W.; He, E.P.; Yuan, B.Z. Thermodynamics Data Calculation Manual of High Temperature Water Solution, 1st ed.; Metallurgical Industry Press: Beijing, China, 1983; pp. 88-648.

32. Mu, W.Z.; Zhang, T.A.; Dou, Z.H.; Lü, G.Z.; Liu, Y. $\varphi-p H$ diagram of V-Ti- $\mathrm{H}_{2} \mathrm{O}$ system during pressure acid leaching of converter slag containing vanadium and titanium. Trans. Nonferrous Met. Soc. China 2011, 21, 2078-2086. [CrossRef]

(C) 2016 by the authors; licensee MDPI, Basel, Switzerland. This article is an open access article distributed under the terms and conditions of the Creative Commons Attribution (CC-BY) license (http://creativecommons.org/licenses/by/4.0/). 